\title{
The local knowledge of the rural people on species, role and hunting of birds: Case study in Karangwangi Village, West Java, Indonesia
}

\author{
JOHAN ISKANDAR ${ }^{1}$, BUDIAWATI SUPANGKAT ISKANDAR ${ }^{2}$, RUHYAT PARTASASMITA ${ }^{1 . \vee}$ \\ ${ }^{1}$ Department of Biology, Faculty of Mathematics and Natural Sciences and Postgraduate of Environmental Study (PSMIL \& DIL) and Institute of \\ Ecology (PPSDAL), Universitas Padjadjaran. Jl. Raya Bandung-Sumedang Km 21, Jatinangor, Sumedang 45363, West Java, Indonesia. Tel +62-22- \\ 7797712. "email: ruhyat.partasasmita@unpad.ac.id \\ ${ }^{2}$ Department of Anthropology, Faculty of Social and Political Science, Universitas Padjadjaran. Jatinangor, Sumedang 45363, West Java, Indonesia
}

Manuscript received: 3 March 2016. Revision accepted: 17 May 2016

\begin{abstract}
Iskandar J, Iskandar BS, Partasasmita R. 2016.The Local knowledge of the rural people on species, role, and hunting of birds: case study in Karangwangi village, Cidaun, West Java, Indonesia. Biodiversitas 17: 435-446. Based on the ecological history, in the past many villages of in Indonesia including in West Java had a high diversity of birds. Nowadays, however, the diversity of birds in some villages of West Java has tended to decrease due to many factors, namely habitat loss, the use of pesticides, and intensive illegal bird hunting. The objective of this paper is to elucidate the local knowledge of Karangwangi village, West Java on species, role, and hunting of birds. Method used in this study is the qualitative and ethnoornithological approach with descriptive analysis. Results of study show that the Karangwangi people have a very good knowledge on bird species, particularly on level species/specific. Various bird species are traditionally classified into nine local categories (folk classification), namely based on distinctive voice/vocalization, morphological characteristic, special color, distinctive behavior, time activity, special common habitat, migrant, nest characteristics, and role in the ecosystem. Based on the rural people perception, the role of birds can be divided into two categories, namely notorious and beneficial birds. The diversity of rural birds has tended decrease over time due to various factors, including illegal bird hunting for various purposes of the village people, such as keep a bird in cages and bird trading. The study suggests the perception of rural people on birds have changed caused of socio-economic and cultural changes. Nowadays the bird hunting in the rural area has tended to shift from a purely subsistence form towards a more commercial form and, thus, to conserve bird species the study on ethnoornithology considered as a very important, and socio-economic and cultural rural people aspects might be integrated to national as well as international bird conservation programs.
\end{abstract}

Keywords: Bird classification, bird hunting, ethnoornithology, Karangwangi, local knowledge

\section{INTRODUCTION}

Indonesia recognized as one of the countries that has a high diversity of birds in the world after Brazil. It has been recorded 1.605 species of birds in Indonesia consists of 20 orders and 94 families, representing 16 percent of total bird species in the word (Bird Life International 2003; LIPI 2014). Indeed, Java island one of the major islands in Indonesia has also rich avifauna. According to Delacour (1947) 337 breeding species have been recorded in this island. While Hoogerwerf (1948) recorded 536 species and sub-species of birds in Java and the surrounding island, representing 410 species and sub-species of breeding, 111 species and sub-species of migrants, 13 species and subspecies stragglers, and 2 species and sub-species of unknown status. Various birds have an important role in ecological services or ecological functions, such as seed dispersal, pest predator, pollinator, and indicator of the environmental pollution and environmental changes (cf. Dammerman 1929; Dickinson et al. 1979; Howe and Westley 1988; Iskandar 2007; Iskandar 2015 ; Sodhi et al.2011). In addition, the birds have socio-economic and cultural functions, such as for food, pet, pet trade, source of fables, tales, stories, folk songs, proverbs, symbolic, myths, and magic (cf. Iskandar 2007; Iskandar 2015a; Kizungu et al. 1998; Jepson and Landle 2005; Alves 2009; van Vloeg and van Weerd 2010; Tidermann et al. 2011; Alves et al., 2013; Bezerra et al. 2013; Roldan Clara et al. 2014; Teixeira et al., 2014; Dandeniya et al. 2015; Partasasmita et. 2016).

Although various birds have an important role both in ecological and socio-economic functions, a lot of birds have been threatened in the village ecosystems of Indonesia, including in West Java in the last several decades. Consequently, some bird species have been recorded became rare or local extinct. Nowadays, it has been recorded some birds considered as globally (near) threatened in Java and Bali, such as Javan hawk eagle (Spizaetus bartelsi), grey-headed fish eagle (Ichthyophaga ichthyaetus), green peafowl (Pavo muticus), yellowthroated hanging-parrot (Loriculus pusillus), black-banded barbet (Megalaema javensis), white-breasted babbler (Stachyris grammiceps), white-bellied fantail (Rhipidura euryura) and straw-headed bulbul (Pycnonotus zeylanicus) (Van Balen 1999). Many factors have affected bird population in village ecosystems, such as habitat loss, the use of pesticides, and intensive illegal bird hunting (cf. van Balen 1999; Sodhi et al. 2011; Iskandar 2007; Iskandar 2015a; Iskandar and Iskandar 2015; Iskandar 2016). Therefore, the main factor that has caused affected bird 
population in the village ecosystem namely human activities (cf. Alves et al. 2013; Iskandar 2015 ). Originally based on the ecological or environmental history, the village people had utilized birds based on local knowledge (corpus) and cosmos and beliefs (Toledo 2002). For example, most Sundanese villages of West Java had perceived some top predator birds, such as serak or barn owl (Tyto alba) and loklok (Family Strigiformes) as strongly related as mystic or magic (cf. Iskandar 2007; Partasasmita et al. 2016). In addition, traditionally if the village people had very frequently heard voice uncuing (cuckoos) and gagak (crows) that is considered as early warning there is a person might be pass away in their community member (cf. Iskandar 2007; Muiruri and Maundu 2011; Badriansyah et al. 2015). As a result, culturally those birds had been considered as scary birds and prohibited hunted. Indeed, those birds had rarely kept as pet and indirectly conserved by the village people. In addition, the forests that had culturally considered as sacred places and traditionally managed by the village people recorded owning a high diversity birds compared with that of in non-sacred places (cf. Iskandar 1998; Endri et al., 2015; Badriansyah et al. 2015).

Nowadays, however, some local knowledges as well as cosmoses of belief of village people in birds have eroded. The village birds have been intensively hunted not only for food and live bird keeping in the cages but also for both trading in local villages and trading in urban bird markets (cf. Jepson and Ladle 2005; Jepson 2011; Pangau adam et al. 2011; Iskandar 2015 ${ }^{\mathrm{b}}$, Iskandar and Iskandar 2015). A lot of birds are currently hunted by the village people because various birds can be traded with high prices. Consequently, the populations of the village birds have dramatically decreased. In addition, intensive use of pesticides in the agriculture and habitat loss through land use conversion have seriously affected on the bird populations in the village area.

Because the village bird populations have tremendously decreased mainly caused of the human actions, therefore, to conserve the village bird populations, the socio-economic and cultural aspects must be considered. Indeed, the study on ethnoornithology - the study of bird in culture-useful to support the bird conservation. Due to the study on ornithology that is concerned in the complex of interrelationship between birds, and all other living and nonliving things (Tidemann et al. 2011).

Due to main source of the problems of threatened birds as well as the hope for solution is the human, we cannot talk about bird conservation without incorporating human dimensions (Alves 20012; Alves et al. 2013; Alves and Souto 2015). Ethnoornithology study of birds in cultures or an understanding of the place of birds in cultures, broadly study to the complex of inter-relationships between birds, humans and all other living and non-living things (Tidemann et al. 2010). Therefore, the result of the ethnoornithology studies can provide basic information for designing urgent conservation strategies, as well as promoting public policies (cf. Jepson 2011; Alves 2012; Alves et al. 2013; Bezera et al. 2013). Although the ethnoornithology is a very important, the ethnoornithology has not yet become well integrated within avian conservation (Bonta 2011). Indeed, study on ethnoornithology studies have rarely undertaken in Indonesia.

The objective of this paper is to elucidate the local knowledge of Karangwangi village, West Java on species, role, and hunting of birds.

\section{MATERIALS AND METHODS}

\section{Materials}

Some materials were used in this study, including the field guide books to the birds for bird identification, written by Delacour (1947), Hoogerwerf (1949a, 1949b), King et al. (1975); and Mac.Kinnon et al. (1992). In addition, some materials were used, namely binocular, GPS, camera, note book, and ballpoint.

\section{Study area}

Study was conducted in the Village (desa) of Karangwangi, Sub-district (kecamatan) of Cidaun, District (kabupaten) of Cianjur, Province (provinsi) of West Java, Indonesia. Geographically, the study area, village of Karangwangi lies between $7^{\circ} 25^{\prime}-30^{\prime} \mathrm{LS} 7^{\circ}$ and $107^{\circ} 23^{\prime}-$ $107^{\circ} 25$ 'E (Figure 1). The Karangwangi village is a remote area which has size of approximately $1,527.80$ hectares that lies off the south of West Java. It has the distance approximately $120 \mathrm{~km}$ from the town of Bandung and approximately $70 \mathrm{~km}$ from the town of Cianjur, and to reach this area by vehicle needs a travel time of 5-6 hours from the town of Bandung and approximately 3-4 km from the town of Cianjur. Karangwangi village is directly bordered with Indian Ocean in the south and the nature conservation of Bojonglarang Jayanti in the west. Land used of the Karangawngi comprises the settlement and home garden, mixed garden, rice field, river, and the forest. In 2014, population of the Karangwangi was recorded 5,672 people consists of 2,864 males and 2,808 females, with total 1,691 households.

\section{Procedure}

Method was used in this study namely the qualitative with descriptive analysis which the ethno-ornithology or ethnobiology approach was applied (cf. Ellen 1993a; Ellen 1993b; Diamond and Bishop 1999; Newing et al. 2011; Iskandar 2012; Albuquerque et al. 2014). Some collecting field data techniques, such as observation, participant observation, and semi-structure or deep interview were applied. During the field research, the researcher stayed in the village between two and three weeks. For collecting ethnoornithology data, the researcher conducted deep interview with informants who was purposively selected by the snowball technique (cf. Newing et al., 2011; Albuerque et al. 2014). Some informants were selected namely old people, the village formal and informal leaders, farmers, fishermen, bird hunters, and wild bird keepers in the village. Before conducting deep interview with informants, the nature and objective of the research were explained, and permission for the interviewees was requested to record information (cf. Alves et al. 2013). The interview 
guideline contained namely the local name/vernacular name of birds, morphological characteristics, distinctive voice, special color, habitat types, and role in ecosystem and socio-cultural, and hunting of birds. To identify and validate bird species for interviewees, the researcher showed bird pictures which are presented in the books of field guide to the birds in Java, Western Indonesia, and Southeast Asia (Hoogerwer 1949a; Hoogerwerf 1949b; King et al. 1975; MacKinnon et al. 1992). In addition, the participant observation was also conducted by researcher during the field research (Newing et al. 2011). For example, the researcher involved in bird hunting activities, namely went to the forests with the informants who were hunting birds.

In addition, to know existing birds and relative population of each bird species in the village study (Karangwangi village), special bird census was conducted by 'IPA' (Indices Ponctuele d'Abondance) or "PIA" (Point Index of Abundance) method (cf. Blondel et al. 1970; Iskandar 1980, van Helvoort 1981; Bibby et al. 1992). The IPA was undertaken by selecting special points at the different habitats, such as mixed-garden (kebon tatangkalan), coastal (pantai), and the forest area (leuweung) of the Nature Conservation of Bojonglarang, Karangwangi. In each point, researcher recorded all birds seen or heard in 15 minutes. Thus, total birds were collected in 46 point counts or IPAs, representing mixedgarden (6 counts), coastal (5 counts) and the forest of Nature conservation of Bojonglarang Jayanti (35 counts).

The various field data collected by observation and deep interviews were analyzed by cross-checking, summarizing and synthesizing, and to building up a narrative account (cf. Newing et al. 2011). While the data of bird population undertaken by the IPA-censuses were analyzed by calculating the index of dominance of each bird (Jorgensen 1976; Van Helvoort 1981) as follow:

$\mathrm{D}_{\mathrm{i}}=\mathrm{N}_{\mathrm{i}} / \mathrm{N} \times 100 \%$ or $\mathrm{Di}=100 \times \mathrm{pi}$
Whereby:

$\mathrm{D}_{\mathrm{i}}=$ dominance value of bird species $\mathrm{i}$;

$\mathrm{N}_{\mathrm{i}}=$ number of individuals belonging to bird species $\mathrm{i}$;

$\mathrm{N}=$ total number of bird individual in the community (the sum of all $\mathrm{N}_{\mathrm{i}}$ )

$\mathrm{P}_{\mathrm{i}}=$ the proportion of the bird individuals of the $\mathrm{i}$-th species of all bird individuals of the community

Moreover bird population can be divided into 3 categories: $\mathrm{Di}=0-2 \%$ (non-dominant), $\mathrm{Di}=2-5 \%$ (subdominant), and $\mathrm{Di}=$ over $5 \%$ (dominant).

\section{RESULTS AND DISCUSSION}

\section{Local knowledge on birds}

The Karangwangi people term for birds generally is manuk. On the basis of folk classification as mentioned by Berlin (1992), the Karangwangi people recognize three taxonomic levels, namely the level of life form manuk (bird), followed by species, equivalent to Western biological classification, such as cangkurileung (Sootyheaded bulbul, Pycnonotus aurigaster), and divided into two sub-species or variations, culturally named cangkurileung kapas (kapas literally cotton or whitish meaning the whitish color of cangkurileung) and cangkurileung kotok (kotok literally chicken or dark, meaning dark color of cangkurileung) (Table 1).

As it can be seen from an example above that the Karangwangi people well recognize the bird classification particularly at the level two which is analog with species in term of biological scientific classification. The folk classification of Karangwangi people is similar to Karam (Bulmer 1967), Katengan (Diamond and Bishop 2000), and Wola, Papua New Guinea in that it has well recognized the bird classification particularly at the level two, species/specific.

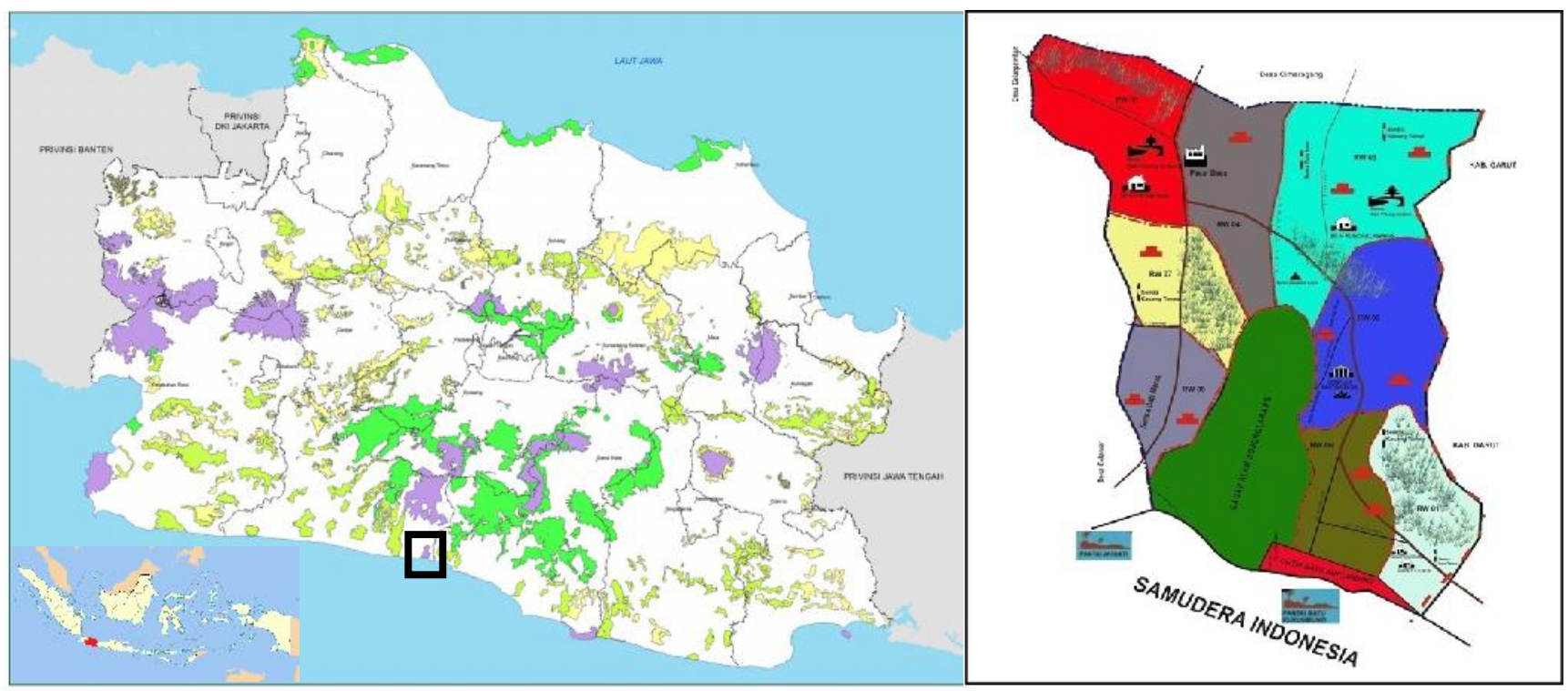

Figure 1. Research location, Karangwangi Village, Cidaun Sub-district, Cianjur District, West Java, Indonesia 
On the basis of our interview with informants, it can be revealed that the Karangwangi people recognized at least 41 bird species. While based on the bird population study using IPA-censuses, it was recorded 40 bird species. These can be divided into 3 categorized, Dominant birds ( $\mathrm{Di}=>$ $5 \%$ ) recorded 5 species, Halcyon chloris (Di=6,87\%), Lonchura leucogastroides ( $\mathrm{Di}=26.87)$, Passer montanus (Di=7.32\%), Treroron curvirostra (Di=9.92\%), and Zosterops palpebrosus ( $\mathrm{Di}=7.48 \%$ ); sub-dominant birds $(\mathrm{Di}=2-5 \%)$ recorded 8 bird species, Collocalia esculenta ( $\mathrm{Di}=2.13 \%)$, Halcyon cyanoventris $(\mathrm{Di}=2,44 \%)$, Megalema australis (Di=4.42\%), Nectarinia jugularis (2.44\%); Orthotomus ruficeps ( $\mathrm{Di}=2.13 \%)$, Orthotomus sepium (Di=4,58\%), Pycnonotus aurigaster (Di=4,88\%) and Treron griseicauda $(\mathrm{Di}=3.96 \%)$, and 27 bird species are categorized as non-dominant birds $(\mathrm{Di}=<2 \%$ ) (Table 2).

Totally bird species recorded both by the IPA-censuses and well recognized by informants of Karangwangi people were 51 bird species representing 14 species (24\%) recognized as the protected animals based on Indonesian law (cf. Noerdjito et al. 2001). Of 19 bird species were recorded both by direct observation using IPA-censuses as well recognized by informants. Several bird species, such as bueuk (Collared scopsowl, Otus bakkamoena/lempiji), koreak (Barn owl, Tyto alba), and cuhcur (Large-tailed Nightjar, Caprimulgus macrurus) were well recognized by the informant but were not recorded by IPA-censuses. Due to these birds are recognized as nocturnal birds and were not recoded by the IPA-censuses recorded during the daytime. In addition, other bird species, such as kerak kebo (Javan myna, Acridotheres javanicus), kangkareng (Hornbill, Anthracoceros sp.), heulang hideung (Blackeagle, Ictinaetus malayensis), and paok (Banded-pitta, Pitta guajana) were not recorded by the IPA-cencuses because these bird populations have been very rare based on the Karangwangi people perception. Conversely, several bird species, such as Abroscopus superciliaris, Acrocephalus orientalis, and Gerygone sulphurea, were recorded by IPAcensuses but these birds were not well recognized by informants. Because these birds might be have small size and commonly lived in the remote forests, and have not culturally given attention by the Krangwangi people.

\section{Folk classification and naming bird species}

On the basis of the deep interview with informants of Karangwangi people, it has been revealed that 41 bird species are well recognized by the local people. These are classified on the basis of distinctive voice/vocalization, morphological characteristic, special color, distinctive behavior, time activity, nest type, habitat, migrant, and role in the ecosystem (Table 3).

\section{Distinctive voice}

Bird voice or bird vocalization is the most significant aspects in naming birds in Karangwangi culture. Many bird species, for example, Cipeuw (Aegithina tiphia), cuhcur (Caprimulgus macrurus), dudut (Centropos sinensis), gagak (Corvus enca), perkutut (Geopelia striata), kahkeh/kehkeh (Halcyon chloris), cekakak (Halcyon cyanoventris), toed (Lanius schach), piit (Lonchura leucogastroides), Ungkut-ungkut (Megalema haemacepahala), and Prenjak (Orthotomus ruficeps) are culturally given vernacular name based on specific vocalization. Similarly, other bird species, such as bueuk (Ottus bakamoena/lempiji), paok (Pitta guajana), Cininin/pacikrak (Prinia familiaris), ekek (Psittacula alexandri), cangkurileung (Pycnonotus aurigaster), jogjog (Pycnonotus goivier), tikukur (Streptopelia chinensis), and koreak (Tyto alba) are attributed by characteristic vocalization (Table 3 ).

Like Sundanese people of Karangwangi, the Malay people of Malaysia have also recognized some vernacular names of bird species based on characteristic vocalization. For example, uwak-uwak (Amaurornis poenicurus), cerewit (Lobivanellus indicus), tekukor (Streptopelia chinensis), but-but or bubut (Centropus sinensis), berek-berek (Merops viridis), and tiong (Gracula religiosa) are culturally given vernacular name based on vocalization characteristic (Madoc 1976). Similarly, local people of Veddah in Sri Lanka have recognized many distinctive bird species based characteristic vocalization (Dandeniya et al. 2015).

\section{Morphological characteristic}

Morphological characteristic of bird species has been significantly considered to folk classify and given vernacular name by the Karangwangi people: Dicrurus macrocercus and Zosterops palpebrosa are case in point. The Dicrurus macrocercus (Black drongo) is attributed a vernacular name by the Karangwangi as saeran gunting because this bird has a characteristic that its tail has a scissor shap (gunting). Similarly, Zosterops palpebrosus (Oriental white-eye) is well recognized as manuk kacamata because this bird has diagnostic mark, based on the local people it has a very distinct the white eye ring which is similar to glasses sharp (kacamata).

Table 1. The three taxonomic levels of bird classification of Karangwangi people

\begin{tabular}{llll}
\hline Level & Class & English equivalent & Rank \\
\hline 0 & Sato & Wild animal & Unique beginner \\
1 & Manuk & Bird & Life-form \\
2 & Cangkurileung & Sooty-headed bulbul & Species/specific \\
3 & Cangkurileung kapas & White-sooty-headed bulbul & Sub-species \\
& Cangkurileung kotok & Bluish-sooty-headed bulbul & Sub-species \\
\hline
\end{tabular}


Table 2. Various bird species identified by the local people and recorded by the Point Count Index (PIA) in Karangwangi, Cidaun, West Java, Indonesia

\begin{tabular}{|c|c|c|c|c|c|}
\hline Scientific name & Family & English name & $\begin{array}{c}\text { Index of } \\
\text { Abundance* } \\
(\%)\end{array}$ & $\begin{array}{c}\text { Identified } \\
\text { by local } \\
\text { people } * *\end{array}$ & Vernacular name \\
\hline Abroscopus superciliaris & Sylviidae & Yellow-bellied warbler & 0.15 & - & - \\
\hline Acridotheres javanicus & Sturnidae & Javan Myna & - & + & Kerak kebo \\
\hline Acrocephalus orientalis & Sylviidae & Eastern Reed Warbler & 0.45 & - & - \\
\hline Acrocephalus stentoreus & Sylviidae & Clamarous Reed-Warbler & 0.30 & - & - \\
\hline Aegithina tiphia & Aegithinidae & Common-Iora & 0.30 & + & Cipeuw \\
\hline Alcedo caurelescens $(\mathrm{p})$ & Alcedinidae & Small blue Kingfisher & 0.45 & - & - \\
\hline Alcedo meninting $(\mathrm{p})$ & Alcedinidae & Blue-eared Kingfisher & 0.91 & - & - \\
\hline Alcippe pyrrhoptera & Timaliidae & Javan Fulvetta & 0,91 & - & - \\
\hline Anthracoceros sp. & Bucerotidae & Hornbill & - & + & Kangkareng \\
\hline Antheptes malacensis (p) & Necatariniidae & Plain-throated Sunbird & 0.30 & - & \\
\hline Anthreptes singalensis (p) & Nectariniidae & Ruby-cheeked Sunbird & 0.30 & - & \\
\hline Cacomantis sp. & Cuculidae & Cuckoo & - & + & Uncuing \\
\hline Caprimulgus macrurus & Caprimulgidae & Large-tailed Nightjar & - & + & Cuhcur \\
\hline Centropus sinensis & Cuculidae & Greater Coucal & 0.30 & + & Dudut \\
\hline Collocalia esculenta & Apodidae & Glossy swiftlet & 2.13 & + & Kapinis \\
\hline Collocalia fuciphaga & Apodidae & Edible-nest Swiftlet & - & + & Kapinis guha \\
\hline Copsychus saularis & Turdidae & Magpie Robin & 0.45 & + & Kacer \\
\hline Corvus enca & Corvidae & Slender-billed Crow & - & + & Gagak \\
\hline Dicaeum trigonostigma & Diceidae & Orange-bellied Flowerpecker & 0.30 & - & - \\
\hline Dicaeum trochileum & Diceidae & Scarlet-headed Flowerpecker & 0.15 & - & - \\
\hline Dicrurus macrocerceus & Dicruridae & Black Drongo & - & + & Saeran \\
\hline Dicrurus paradisieus & Dicruridae & Greater Racket-tailed Drongo & - & + & Saeran rame \\
\hline Egretta sacra $(\mathrm{p})$ & Ardeidae & Pacific Reef-egret & 0.91 & + & Kuntul \\
\hline Gallus gallus bankiva & Phasianidae & Red Junglefowl & 0.91 & + & Cangehgar \\
\hline Geoplelia striata & Columbidae & Zebra-Dove & - & + & Perkutut \\
\hline Gerygone sulphurea & Sylviidae & Golden-bellied Gerygone & 0.15 & - & - \\
\hline Halcyon chloris $(\mathrm{p})$ & Alcedinidae & Collared Kingfisher & 6.87 & + & Kahkeh/ kehkeh \\
\hline Halcyon cyanoventris (p) & Alcedinidae & Javan Kingfisher & 2.44 & + & Cekakak \\
\hline Haliaeetus leucogaster (p) & Accipitridae & White-bellied Fish-Eagle & 0.45 & + & Heulang bodas \\
\hline Hirundo striola & Hirundinidae & Striated Swallow & 0.15 & - & Kapinis belang \\
\hline Hirundo tahitica & Hirundinidae & Pacific Swallow & 0.15 & - & Kapinis bodas \\
\hline Icitinaetus malayensis $(\mathrm{p})$ & Acciptridae & Black Eagle & - & + & Heulang hideung \\
\hline Lanius scach & Laniidae & Long-tailed Shrike & - & + & Toed \\
\hline Lonchura leucogastroides & Ploceidae & Javan Munia & 26.87 & + & Piit \\
\hline Macropygia emiliana & Clumbidae & Ruddy Cuckoo-Dove & 1.83 & - & - \\
\hline Megalema armilaris ( $\mathrm{p})$ & Capitonidae & Orange-fronted Barbet & 0.15 & - & - \\
\hline Megalema australis & Capitonidae & Blue-eared Barbet & 4.42 & - & - \\
\hline Megalema haemacephala & Capitonidae & Coppersmith Barbet & - & + & Ungkut-ungkut \\
\hline Nectarinia jugularis $(\mathrm{p})$ & Nectariniidae & Olive-backed Sunbird & 2.44 & - & - \\
\hline Orthotomus ruficeps & Sylviidae & Ashy Tailorbird & 2.13 & + & Prenjak \\
\hline Orthotomus sepium & Sylviidae & Olive-backed Tailorbird & 4.58 & + & Prenjak \\
\hline Orthotomus sutorius & Sylviidae & Common Tailorbird & 0.45 & + & Prenjak \\
\hline Otus bakkamoena (lempiji) & Strigiformes & Collared Scopsowl & - & + & Bueuk \\
\hline Passer montanus & Ploceidae & Eurasian Tree Sparrow & 7.32 & + & Galejra \\
\hline Pitta guajana $(\mathrm{p})$ & Pittidae & Banded Pitta & - & + & Paok \\
\hline Ploceus sp. & Ploceidae & Munia & - & + & Manyar \\
\hline Prinia familiaris & Sylviidae & Bar-Winged Prinia & 0.30 & + & Cininin/pacikrak \\
\hline Psittacula alexandri & Psittacidae & Red-Breasted Parakeet & - & + & Ekek \\
\hline Pycnonotus aurigaster & Pycnonotidae & Sooty -headed Bulbul & 4.88 & + & Cangkurileung \\
\hline Pycnonotus goiavier & Pycnonotidae & Yellow-vented Bulbul & 1.37 & + & Jogjog \\
\hline Spilornis cheela $(\mathrm{p})$ & Accipitridae & Crested Serpent Eagle & - & + & Heulang coklat \\
\hline Streptopelia bitorquata & Columbidae & Island Collared-Dove & 0.61 & - & - \\
\hline Streptopelia chinensis & Columbidae & Spotted-Dove & 0.91 & + & Tikukur \\
\hline Treron curvirostra & Columbidae & Thick-billed Green-Pigeon & 9.92 & + & Walik \\
\hline Treron griseicauda & Columbidae & Grey-cheeked Green Pigeon & 3.96 & + & Walik \\
\hline Tyto alba & Strigiformes & Barn Owl & - & + & Koreak \\
\hline Zoothera citrina & Turdidae & Orange-headed Thrush & - & + & Anis \\
\hline Zosterops chloris & Zosteropidae & Lemon-bellied White-eye & 0.61 & + & Manuk kacamata \\
\hline Zosterops palpebrosus & Zosteropidae & Oriental White-eye & 7.48 & + & Manuk kacamata \\
\hline
\end{tabular}

Note: *) - Not recorded by IPA censuses; (p) Protected birds based on Indonesian regulation (Regulation No.5, 1990, on the biodiversity and ecosystem conservation. 
Like Karangwangi, the local people Malay of Malaysia have also culturally attributed various vernacular names of bird species based on distinctive morphological diagnostic: burong botak (Lesser adjutant, Leptoptilos javanicus) and belatok kecil (Sunda Woodpecker, Dendrocopos moluccensis) (Madoc 1976). In addition, the Leptoptilos javanicus is perceived by the local people of Malay has a diagnostic mark as a bald head bird (burong kepala botak) due to her head bald (botak). Similarly, the Dendrocopos moluccensis has been popularly called as belatok kecil because this bird has small size compared to other woodpecker bird family (Family Picidae).

\section{Special color}

Many birds have been culturally recognized by local people of Karangwangi with own specific vernacular name based on special color. For example, Haliaeetus leucogaster (White-bellied fish-eagle) has been culturally named as heulang bodas due to general color of feather is white (bodas), particularly the head and neck and underparts of the adult bird are white (bodas). Similarly, Ictinaetus malayensis (Black-eagle) and Spilornis cheela (Crestedserpent-eagle) are popularly recognised by Karangwangi as heulang hideung and heulang coklat, respectively because the Ictinaetus malayensis has all part black color (hideung) and Spilornis cheela has appearing to be brown (coklat), except in the tip of the tail has a broad white band. Like the Karangwang, the local people of Veddah in Sri Lanka (Dandeniya et al. 2015) and the Malay people of Malaysia (Madoc 1976), have also popularly recognized some birds which is given vernacular name based on special color. For example, Munia maja (White-headed munia) is famously named as pipit uban in the Malay people of Malaysia due to her head has color white or metaphoric as gray hair (uban). Another example, Dinopium javanense (Common golden back woodpecker) has been culturally called as belatok mas in the Malay, because this bird has diagnostic mark at the upper back and the wing-coverts are golden yellow similar golden color (mas).

\section{Distinctive behavior}

Some birds are culturally classified by local people of Karangwang based on characteristic behavior of those birds. Manuk kerak kebo (Javan Myna, Acridotheres javanicus), for example, has been given name by the local people because the behavior of this birds usually looking for food types of insects, particularly grasshopper near buffalo being herded in the rice field or grazing grassland. Similarly, this bird has been also commonly called by the Malay people of Malaysia as gembala kerbau (grazing buffalo) due to behavior of this bird usually looking for insects in grazing buffalo (cf. Madoc 1976). Another example, Dicrurus paradiseus (Greater racket-tailed drongo) has been culturally recognized by local people of Karangwangi as saeran rame (noisy drongo) because this bird has specific behavior which is perceived as 'noisy voice'.

\section{Time activity}

Local people of Karangwang's taxonomy have two distinct groups as 'diurnal bird species' or active birds at the daytime (manuk biasa liar siang) and "nocturnal bird species (manuk liar peuting). On the basis of the local people of Karangwangi most birds are considered as diurnal birds. However, some birds are culturally recognized as nocturnal birds, such as cuhcur (Large-tailed nightjar, Caprimulgus macrurus), bueuk (Collared scopsowl, Otus bakkamoena/lempiji), and koreak (Barnowl, Tyto alba). Like all nightjar birds, the cuhcur starts working for insect at sunset. In the daytime it may be found hiding beneath trees and bushes in the mixed garden or secondary forest. Almost everyone of Karangwangi has been familiar with the vocalization of this bird as cur-curcur. Bueuk (Collared Scopsowl, Ottus bakkamoenal lempiji) is a night bird. At the night time, this bird has frequently heard her voice instead of directly seen. The voice of bueuk has culturally herd as 'bueuk-boeuk-bueuk'. Conversely, this bird usually takes rest in the mixed-garden or in the hole of wood tree. Similarly, koreak usually goes out from her resting places in the afternoon, such as house building and other buildings to find foods, namely rate. They usually fly from one place to other places which have distinctive voice as koreak-koreak-koreak.

\section{Nesting type}

The local people of Karangwangi village have categorized some birds based on nesting type and nesting characteristic. For example, manuk manyar (Streaked Weaver, Ploceus manyar) has been considered as the builders of wonderful nests. Conversely, tikukur (Spotted Dove, Streptopelia chinensis) considered as big bird size but it has been well known has bad and simple nesting type. Her nest is usually made of dried tree twig which relative small size. The local people of Karangwangi have also well recognised that manuk uncuing (cucoo birds) is a real parasite, and its eggs have usually put in the nest of manuk Prenjak (Tailor-birds, Orthotomus sp.). While, manuk kapinis gua or walet (Edible-nest Swiflet, Collocalia fuciphaga) recognised has distinctive nest in the cave and edible nest.

Like Karangangi the Veddah of Sri Lanka have culturally categorized birds, such as based on habits of birds and nesting behavior. For example, Streaked Weaver bird has been considered as interesting birds, such as this bird able to make unique nest (Dandeniya et al. 2015).

\section{Habitat type}

Some birds have traditionally categorized by the local people of Karangangi based on the habitat characteristic. On the basis of the interview with informants, it has been revealed that some birds have been categorized as village, icefield, forest, and coastal birds. For example, manuk kangkareng (Hornbill, Anthracoceros sp.), cangehgar (Red jungle fowl, Gallus gallus bankiva), walik (Green-pigeon, Treron sp.), and merak (Green Peafowl, Pavo muticus) are categorized as the forest birds. Heulang bodas (Whitebellied fish-eagle, Haliaeetus leucogaster) and kuntul (Pacific Reef-egret, Egreta sacra) are culturally categorized as the coastal birds. Manuk gereja (Eurasian Tree Sparrow, Passer montanus), Prenjak (Ashy Tailorbird, Orthotomus ruficeps), and cangkurileung (Sooty- 
headed Bulbul, Pycnonotus aurigaster) are recognized as the village birds. While, piit (Javan Munia, Lonchura leucogastroides), manyar (Streaked-Weaver, Ploceus manyar), peking (Scaly-breasted Munia, Lonchura punctulata), and bondol (White-headed Munia, Lonchura maja) are categorized as the Richfield birds. In addition, cekakak (Javan Kingfisher, Halcyon cyanoventris) is categorized as the riverbank bird or close to water bodies.

\section{Migrant}

Some birds, such as bondol (White-headed Munia, Lonchura maja), pipit (Javan Munia, Lonchura leucogastroides), peking (Scaly-breasted Munia, Lonchura punctulata) and ekek (Red-breasted Parakeet, Psittacula alexandri), and kuntul (Javan Pond Heron, Ardeola speciosa) have been categorized by the local people of Karangwangi as local migrant birds. On the basis of the local people perception, bondol, pipit, peking and ekek have been predominantly found in the rice field (sawah) and the swidden field (huma), but after finishing rice harvesting they have locally migrated to other villages. Similarly, population of manuk kuntul has been predominantly found in the many wetlands during the rainy season but they usually move to other places and will return during the rainy season.

\section{Role in the ecosystem}

Some birds, such as ekek (Red-breasted Parakeet, Psittacula alexandri), pipit (Javan Munia, Lonchura leucogastroides), peking (Scaly-breasted Munia, Loncura punctulata), bondol (White-headed Munia, Lonchura maja) and manyar (Streaked Weaver, Ploceus manyar) are cultural perceived as notorious birds. These birds are categorized as paddy seed eaters. Conversely, bird of kapinis gua or walet (Edible-nest Swiftlet, Collocalia fuciphaga) has been categorized as beneficial bird because the edible nest of this bird can be traded with a very high price. In addition, some raptor birds or top predators, such as heulang coklat (Crested Serpent-eagle, Spilornis cheela) and koreak (Barn owl, Tyto alba) have been categorized as beneficial birds due to rat eaters. Similarly, this bird has been considered as a beneficial bird in other Indonesian ethnics, such as village people of Petapahan, Riau, Sumatera (Badriansyah et al. 2015). In other words, based on the local people perception, the rats as paddy pest in the rice fields (sawah) and swidden farming fields (huma) might be controlled by raptors birds, namely koreak and heulang ruyuk.

The local people of Karangwangi culturally recognize also some birds, such as kapinis (Hirundo sp.) and special butterfly (kukupu) that are frequently observed in their village can be used as indicator of the beginning of the rainy season. Like, Karangwangi people, the local people the Dayak of Sarawak (Smythies 1960) the bird of wagtails, such as burung beras-beras (White wagtail, Motacilla alba) have been be used as beginning of the rainy season or paddy season lot of paddy (beras) in the swidden fields. While, the burung ketupong (Rufous Piculet, Sasia abnormis) has been an important role for the Kantu Dayak in selecting the forest are that can be opened for the swidden farming system (ladang). For example, by existing a lot of this bird in the certain forest area has been used as indicator such forest is not mature forest and not suitable for the planting paddy which might get a lot of terrestrial weeds (Dove 1988). .

\section{Role in sociocultural}

Birds have closely associated with traditions of the local people of Karangawngi or Sundanese people in general. For example, birds have inspired for the local mythology, tale, song, and proverb. On the basis mythology, for example, manuk lok-lok (lok-lok bird of Family Strigiformes) has been considered as 'dreaded bird 'because it has closely related with the Sundanese mythology, this bird become trans. Some birds also considered as bad omen, namely uncuing (Cockoo, Cacomantis sp.) and gagak (Crow, Corvus sp.) (cf.Iskandar 2007; Badriansyah et al. 2015). If people hear continually voice of these birds that is perceived as bad news, may be someone may pass away. Some tales in relation with birds have also been recognized by Sundanese rural people, tale of king of bird (ratu manuk) is case in point (cf. Iskandar 2007). Both songs and proverb of Sundanese in relation to birds are also culturally recognized in rural Sundanese of West Java, including the local people of Karangwangi, Cianjur, West Java.

\section{Local knowledge on hunting birds}

Traditionally hunting wild animals, including hunting birds have been recognized for a longtime in rural area across cultural in the world, including in West Java (cf Iskandar, 1980; Iskandar 2014; Milton and Marhadi 1989; Alves 2012; Alves et al. 2013; Alves and Souto 2015). On the basis of semi-structure interview with informants of the local people of Karawangi, Cianjur, West Java, the hunting birds had been commonly practiced by the Karangwangi people in the last time but now their hunting activities have tended to decrease due to bird population in their village have not abundant anymore.

Culturally, it has been recognized some techniques are predominantly practiced by local people of Karangwangi, namely to glue birds with sap (ngaleugeut/ngelem), to capture birds by nets (ngajaring), to catch birds with torch and kerosene lamp (ngobor), to hunt with a bamboo blowpipe (susumpit), and to hunt with a gun (bebedil) (Stachclyda 2015).

\section{Ngaleugeut/ngelem-to glue birds with sap}

This technique is aimed to catch live birds which are undertaken during the daytime. The main material commonly used for hunting bird by ngaleugeut technique is various sap, such as karet (Hevea braziliensis (Willd) Muell), nangka (Artocarpus heterophyllus Lam), teureup (Artocarpus elasticus Reinw ex Blume) and sirsak (Annona muricata L). The sap is accommodated by container and simmering. The ngaleugeut technique is applied as following. Firstly, the stake bamboo or wood is prepared. Secondly, the bamboo or wood stake is covered by sap. Thirdly, the bamboo or wood stake that is covered by sap is put in the tree that is predominantly visited by birds. Another approach, the selected twigs of tree is covered 
Table 3. Diagnostic characteristic used in Karangwangi, West Java, Indonesia bird classification

\begin{tabular}{|c|c|c|c|c|}
\hline Folk classification & Vernacular name & Scientific name & English name & Description based on rural people perception (emic view) \\
\hline \multirow{20}{*}{$\begin{array}{l}\text { Distinctive voice/ } \\
\text { vocalization }\end{array}$} & Cipeuw & Aegithina tiphia & Common Iora & Voice: ciipeuw ciipeuw ciipeuw \\
\hline & Cuhcur & Caprimulgus macrurus & Large-tailed Nightjar & Voice: cuur cuur cuur cuur \\
\hline & Dudut & Centropus sinensis & Greater Coucal & Voice: duut duut duut duut \\
\hline & Gagak & Corvus enca & Slender-billed Crow & Voice: gaaak gaaak gaaak \\
\hline & Perkutut & Geopelia striata & Zebra-Dove & Voice: perkututut perkututut perkututut \\
\hline & Kahkeh/ kehkeh & Halcyon chloris & Collared-Kingfisher & Voice: kahkeh kahkeh kahkeh or kekhkeh kehkeh kehkeh \\
\hline & Cekakak & Halcyon cyanoventris & Javan Kingfisher & Voice: cekakakak cekakakak cekakakak \\
\hline & Toed & Lanius schach & Long-tailed Shrike & Voice: toed toed toed toed \\
\hline & Piit & Lonchura leucogastroides & Javan Munia & Voice: priet priet priet priet \\
\hline & Ungkut-ungkut & Megalema haemacephala & Coppersmith Barbet & Voice: Ungkut-ungkut ungkut or kut kut kut kut \\
\hline & Prenjak & Orthotomus ruficeps & Ashy Tailorbird & Voice: prienjak prienjak prienjak \\
\hline & Bueuk & Otus bakkamoena/ lempiji & Collared Scopsowl & Voice: buueuk buueuk buueuk \\
\hline & Paok & Pitta guajana & Banded Pitta & Voice: paaok paaok paaok \\
\hline & Cininin/pacikrak & Prinia familiaris & Bar-winged Prinia & Voice: cinininin cinininin cinininin or cikrak cikrak cikrak \\
\hline & Ekek & Psittacula alexandri & Red-breasted Parakeet & Voice: keek keek keek keek \\
\hline & Cangkurileung & Pycnonotus aurigaster & Sooty-headed Bulbul & Voice: dret dret kurileung, kurileung kurileung \\
\hline & Jogjog & Pycnonotus goiavier & Yellow vented Bulbul & Voice: jog jog jog jog \\
\hline & Tikukur & Streptopelia chinensis & Spotted-Dove & Voice: tiikukur tikukur tikukukur or tikukukur guk tikukukur guk \\
\hline & Koreak & Tyto alba & Barn Owl & Voice: kooreak kooreak kooreak \\
\hline & Loklok & Family Strigiformes? & & Voice: loklok loklok loklok \\
\hline \multirow{2}{*}{$\begin{array}{l}\text { Morhological } \\
\text { characteristic }\end{array}$} & Saeran gunting & Dicrurus macroceceus & Black Drongo & The tail is deeply forked and similar to scissor shape (gunting) \\
\hline & Manuk kacamata & Zosterops palpebrosa & Oriental White-eye & The white eye ring is similar to glasses shape (kacamata) \\
\hline \multirow[t]{3}{*}{ Special color } & Heulang bodas & Haliaeetus leucogaster & White-bellied Fish-Eagle & $\begin{array}{l}\text { General color of feather is white, particularly the head and neck and underparts } \\
\text { of the adult bird are white (bodas). }\end{array}$ \\
\hline & Heulang hideung & Ictinaetus ma;ayensis & Black-Eagle & $\begin{array}{l}\text { The magnificent eagle which has appearing to be generally all black color } \\
\text { (hideung) }\end{array}$ \\
\hline & Heulang coklat & Spilornis cheela & Crested Serpent-eagle & $\begin{array}{l}\text { Generally it has appearing to be brown (coklat), except in the tip of the tail has a } \\
\text { broad white band. }\end{array}$ \\
\hline \multirow[t]{3}{*}{ Distinctive behavor } & Manuk kerak kebo & Acridotheres javanicus & Javan Myna & $\begin{array}{l}\text { This bird is frequently seen in rice field and grazing ground very close } \\
\text { interaction with buffalo (kebo), particularly to find insects in the buffalo body or } \\
\text { its surrounding. }\end{array}$ \\
\hline & Saeran rame & Dicrurus paradiseus & Greater Racket-tailed Drongo & $\begin{array}{l}\text { This bird has characteristic behavior, it has been considered as noise voice } \\
\text { (rame) }\end{array}$ \\
\hline & Manuk saleser & Sitta azurea & Blue-Nuthatch & $\begin{array}{l}\text { This bird can be frequently seen running up the trunt of a tree or it seem to be } \\
\text { creeping (nyaleser). }\end{array}$ \\
\hline
\end{tabular}




\begin{tabular}{|c|c|c|c|c|}
\hline \multirow[t]{2}{*}{$\begin{array}{l}\text { Time activity: } \\
\text { diurnal and } \\
\text { nocturnal }\end{array}$} & Cuhcur & Caprimulgus macrurus & Large-tailed Nightjar & \multirow[t]{2}{*}{$\begin{array}{l}\text { Some birds, such as cuhcur, bueuk, and koreak are active in the night time } \\
\text { (nocturnal) and in the day time it may bee found hiding in the rest places. While } \\
\text { other birds are considered as diurnal birds. }\end{array}$} \\
\hline & $\begin{array}{l}\text { Bueuk } \\
\text { Koreak }\end{array}$ & $\begin{array}{l}\text { Otus bakkamoena/ lempiji } \\
\text { Tyto alba }\end{array}$ & $\begin{array}{l}\text { Collared Scopsowl } \\
\text { Barn Owl }\end{array}$ & \\
\hline Special habitat & $\begin{array}{l}\text { Kangkareng } \\
\text { Cangehgar } \\
\text { Walik } \\
\text { Piit } \\
\text { Manyar } \\
\text { Kuntul } \\
\text { Cangkurileung } \\
\text { Prenjak } \\
\text { Galejra }\end{array}$ & $\begin{array}{l}\text { Anthracoceros albirostris } \\
\text { Gallus gallus bankiva } \\
\text { Treron spp. } \\
\text { Lonchura leucogastroides } \\
\text { Ploceus manyar } \\
\text { Egretta intermedia } \\
\text { Pycnonotus aurigaster } \\
\text { Orthotomus ruficeps } \\
\text { Passer montanus }\end{array}$ & $\begin{array}{l}\text { Oriental pied hornbill } \\
\text { Junglefowl } \\
\text { Green Pigeon } \\
\text { Javan Munia } \\
\text { Streaked Weaver } \\
\text { Intermediate Egret } \\
\text { Sooty-headed Bulbul } \\
\text { Ashy Tailorbird } \\
\text { Eurasian Tree Sparrow }\end{array}$ & $\begin{array}{l}\text { These birds are perceived by local people as forest birds (manuk leuweung) } \\
\text { These birds are perceived by local people as rice field birds (manuk sawah) } \\
\text { These birds are perceived by local people as the coastal birds (manuk pantai) } \\
\text { These birds are perceived by local people as rural birds (manuk kamung/desa) }\end{array}$ \\
\hline Nest characteristic & $\begin{array}{l}\text { Manyar } \\
\text { Tikukur } \\
\text { Perkutut } \\
\text { Caladi } \\
\text { Cekakak }\end{array}$ & $\begin{array}{l}\text { Ploceus manyar } \\
\text { Streptopelia chinensis } \\
\text { Geopelia striata } \\
\text { Dendrocopos macei } \\
\text { Halcyon chloris }\end{array}$ & $\begin{array}{l}\text { Streaked Weaver } \\
\text { Spotted-Dove } \\
\text { Zebra-Dove } \\
\text { Fulvous-breasted woodpecker } \\
\text { Collared-Kingfisher }\end{array}$ & $\begin{array}{l}\text { The manyar nest is popularly recognized by local people as nice and unique } \\
\text { nest. The nest, hung from the tip of branch or palm-frond, is flask-shaped. } \\
\text { Conversely, the tikukur nest is considered by local people as a simple nest } \\
\text { composed by dry branches } \\
\text { Caladi is recognized by local people as has a nest in the tree hole. } \\
\text { Cekakak is considered by local people as has nest in the hole of hill soil. }\end{array}$ \\
\hline Migrant & $\begin{array}{l}\text { Ekek } \\
\text { Pipit } \\
\text { Peking } \\
\text { Kuntul }\end{array}$ & $\begin{array}{l}\text { Psittacula alexandri } \\
\text { Lonchura leucogastroides } \\
\text { Lonchura punctulata } \\
\text { Egretta intermedia }\end{array}$ & $\begin{array}{l}\text { Red-breasted Parakeet } \\
\text { Javan Munia } \\
\text { Scaly-breasted Munia } \\
\text { Intermediate Egret }\end{array}$ & $\begin{array}{l}\text { Many birds, such as ekek, pipit, peking, and kuntul common locally migrate-out } \\
\text { from village to other villages in off paddy farming season and migrate-in to the } \\
\text { village during the paddy farming season. Similarly, kuntul local migate-out from } \\
\text { vill during dry season and migrate-in during the wet aor rainy season. }\end{array}$ \\
\hline $\begin{array}{l}\text { Role in ecosystem: } \\
\text { ecosystem sevices } \\
\text { and cultural } \\
\text { functions }\end{array}$ & $\begin{array}{l}\text { Ekek } \\
\text { Piit } \\
\text { Peking } \\
\text { Manyar } \\
\text { Walet } \\
\text { Cangehgar } \\
\text { Heulang coklat } \\
\text { Koreak }\end{array}$ & $\begin{array}{l}\text { Psittacula alexandi } \\
\text { Lonchura leucogastroides } \\
\text { Lonchura punctulata } \\
\text { Ploceus manyar. } \\
\text { Collocalia fuciphaga } \\
\text { Gallus gallus bankiva } \\
\text { Spilornis cheea } \\
\text { Tyto alba }\end{array}$ & $\begin{array}{l}\text { Red-breasted Parakeet } \\
\text { Javan Munia } \\
\text { Scaly-breasted Munia } \\
\text { Streaked Weaver } \\
\text { Edible-nest Swiftlet } \\
\text { Junglefowl } \\
\text { Crested Serpent-eagle } \\
\text { Barn Owl }\end{array}$ & $\begin{array}{l}\text { Another bird species, such as cangehgar which has behavior to eat seeds, } \\
\text { perceives as seed dispersal and considered as beneficial bird. } \\
\text { Similarly, heulang coklat and koreak are perceived by local people as rat eaters } \\
\text { and considered as beneficial bird. } \\
\text { Cultural functions: birds in song, bird in mythos, bird in tale, and birds in bird } \\
\text { keeping and trading. }\end{array}$ \\
\hline
\end{tabular}


witn sap. Fortn, the tame bira is put near tne pamboo or stake wood or twigs covered by sap. In addition, the bird recording voice of handphone is active. Fifth, the bamboo or stake or twigs are awaited by the bird hunter. Some birds caught by sap are taken and released from the sap using the water or oil. Finally, the hunted birds are collected and put in the cage. In the past, most bird trapped was utilized for bird keeping in the household. Today, however, these bird trapped are traded to middlemen in the village or traded in the urban bird market.

\section{Ngajaring - to capture birds with nets}

Ngajaring technique is aimed to catch life birds by using nets. The nets is made by nylon with has along about $20 \mathrm{~m}$. Procedures to catch birds by using nylon nets as follows. Firstly, the nylon nets are placed in areas where many birds, such as forest, river bank, and rice field. The secondly, the nylon nets are placed for a few hours and awaited by the bird hunters. Thirdly, the nylon nets placed are monitored and birds are trapped by nylon nets are released and put into the special cages. The forth, all bird trapped were utilized as source of protein food in the rural people and kept for bird keeping in the cages. Today, however, most bird trapped are sold to the rural middleman or directly brought to urban and selling in the urban bird markets (Figure 2).

On the basis of information from informants, various bird trapped can be sold in the rural have various price. Some common birds, such as pipit (Lonchura leucogastroides), peking (Lonchura punctulata), kutilang (Pycnnotus aurigaster), and jogjog (Pycnonotus goiavier) are commonly sold in the Krangwangi in a low price (harga murah) approximately between Rp. 20,000 and Rp 50,000. Another not-common bird, such as saeran (Dicrurus macrocerceus) can be sold with moderate price (harga sedang) about between $\mathrm{Rp} 150,000$ and $\mathrm{Rp}$ 200,000. However, some popular bird songs that are popularly and frequently contested in urban areas, such as anis (Zoothera citrina) has commonly traded in the Karangwangi in a high price (harga mahal) between Rp 400,000 and Rp 500,000. However, this bird if is brought to urban and can be sold in more expensive approximately between Rp 700,000 and Rp 5,000,000. Indeed, the anis birds have been docile and good song, have very expensive price, about between Rp 12,000,000-Rp 50,000,000 (Iskandar 2015a).

\section{Ngobor-to catch birds with torch and kerosene lamp}

The ngobor technique is commonly undertaken by the local people of Karangwangi during the night. Some materials, such as kerosene lamp (obor), torch (lampu senter), gun (senapan), and bag (kantung) are commonly used for ngobor. The ngobor are usually conducted by four persons who each person has special duty, namely as carrying kerosene lamp, torch, gun, and bag, respectively. Culturally, procedure to catch birds with torch and kerosene as follows. Firstly, the appropriate place for hunting birds, particularly bird nesting place is decided. Secondly, the torch beam is directed to resting bird and shouted fire by gun. The dead bird shot by gun is taken by one or the bira nunter members. I ne aead bira are collected and divided into 4 persons and brought to hamlet (kampung) for cooking as chief source protein in the urban area.

\section{Susumpit — to hunt with a bamboo blowpipe}

The susumpit technique is used several material, particularly a bamboo blowpipe (sumpit) and dart (passer). The bamboo blowpipe (sumpit) is made of a special bamboo called awi tamiang (Schizostachyum iraten Steud) the long segment of bamboo. The bamboo steak is cut and straightened by heating upper furnaces. To lengthen the bamboo blowpipe is normally spliced by another bamboo segment laced-up by rattan strip and glued to asphalt. The dart (paser) is made of bamboo stake that one of tip is sharpened and little bite burned, and in another tip is covered by kapok and tied by banana tree fiber yarn. A number of drat are commonly made because it will be lost in each blown.

The susumpit is usually undertaken during the daytime. The procedure of hunting birds with a bamboo blowpipe (susumpit) as follows. Firstly, perching bird is observed in different habitats, such as forest, mixed-garden, and river bank. Secondly, the perching bird is carefully approached with appropriate close distance. Thirdly, the targeted perching bird is blown by sumpit and dart goes toward the bird target. Forth, the bird in the dart puncture is collected and brought to the home. The birds obtained by susumpit are commonly utilized for meet cooking and consumed by the household members.

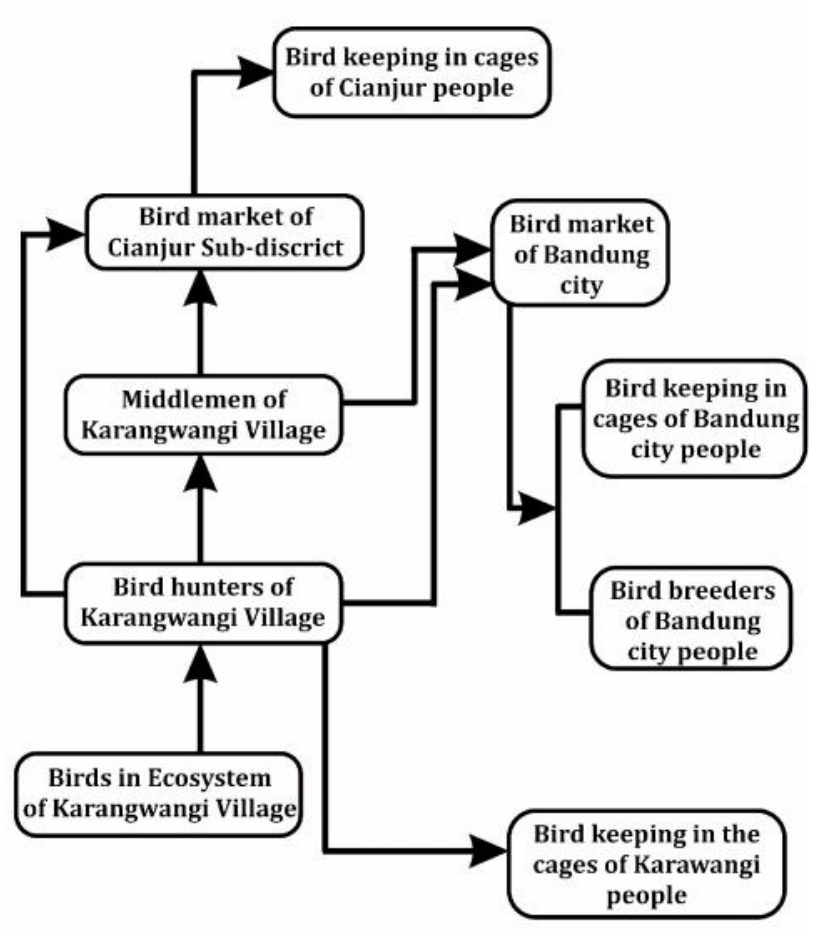

Figure 1. Trading chain of bird in Karangwangi village, West Java, Indonesia 


\section{Bebedil-to hunt with a gun}

Both to hunt birds with a bamboo blowpipe (susumpit) and to hunt a gun (bebedil) have similar purpose namely to kill birds. However, unlike the susumpit, the gun (bedil) is mainly used by the bird hunter. Three types of guns are usually used by the local people of Karangwangi, namely cuplis, senapan angin, and senapan modern. The cuplis is traditionally made by the local people of Karngwangi, while the senapan angin and senapan modern made of urban industry. Procedure of hunting birds a gun (bebedil) is similar to that of the susumpit as follows. Firstly, perching bird is observed in different habitats, such as forest, mixed-garden, and river bank. Secondly, the perching bird is carefully approached with appropriate close distance. Thirdly, the targeted perching bird is shut by gun. Forth, the killed is collected and brought to the home. Like susumpit, the birds obtained by bebedil are commonly utilized for meet cooking and consumed by the household members.

\section{The local knowledge of bird conservation}

In the past, most Sundanese rural people of West Java utilized birds were based on the local knowledge and cosmos or belief (cf. Toledo 2002). For example, some birds such as manuk caladi (Family Picidae), heulang (Family Accipitridae) and alap-alap (Family Falconidae) were culturally prohibited (pamali) to kill and consume (cf. Iskandar 2014; Ekwochi et al. 2016). In addition, based on the local tradition, looking for some birds such perkutut (Zebra dove, Geopelia striata) would be provided 'lucky' (keberuntungan). Conversely, the looking for gagak and uncuing was perceived would bad consequences of bad luck or unfortunate. As a result, some birds of raptors, woodpeckers, gagak and uncuing, have been culturally protected by the Sundanese local people of West Java (Iskandar 2014). Today, however, some culturally prohibitions or taboos (pamali) have been eroded due to rapid socio-economic and cultural changes. For example, based of deep interview with informants, almost all bird species including the protected birds by the government are allowed to capture, kill, and to trade by the rural people. As a result, the populations of some birds in the rural area have rapidly decreased due to over exploitation. Indeed, based on the informant perception, some birds, such as kangkareng (Hornbill, Anthracoceros sp.), cuhcur (Largetailed Nightjar, Caprimulgus macrurus), gagak, gelatik (Great tit, Parus major), merak (Green-Peafowl, Pavo muticus), paok (Banded-Pitta, Pitta guajana), ekek (Redbreasted Parakeet, Psittacula alexandri), kerak kebo (Javan Myna, Acridotheres javanicus), anis (Orange-headedTrush, Zoothera citrina), and ciung (Whisting-thrush, Myiophoneus sp.) have been considered as very rare or already local extinct.

\section{ACKNOWLEGEMENTS}

This study is one of the topics of the program of Academic Leadership Grant (ALG) of Prof. Johan Iskandar, funded by DIPA Universitas Padjadjaran fiscal year 2015/2016. Therefore, on this occasion we would like to thank Prof. Dr. med. Tri Hanggono Achmad, dr. rector of Universitas Padjadjaran, Sumedang, Indonesia who has provided Academic Leadership Grant as implementation to achieve Word Class University. In addition, we also would like to thank the field assistants of the team Biology Unpad, namely Tryesramira Stachclyda, who have assisted collect field data. In this opportunity, we also conveyed gratitude to the village head of Karangwangi village and his staff, along with the informants of Karangwangi who have kindly helped us to provide information.

\section{REFERENCES}

Albuquerque UP, da Cunha LVFC, de Lucena RF P et al. 2014. Methods and Techniques in Ethnobiology. Springer, New York.

Alves RRN, Leite RCL, Souto WMS et al. 2013. Ethno-ornithology and Conservation of wild birds in Semi-Arid Caatinga of Northeastern Brazil. Ethnobiol Med 9 (14).1-12.

Alves RRN, Souto WMS. 2015. Ethnozoology: a brief introduction. Ethnobiol Conserv 4 (1): 1-13.

Alves RRN. 2009. Fauna used in popular medicine in Northeast Brazil. Ethnobio and Ethnomed. DOI: 10.1186/1746-4269-5-1

Alves RRN. 2012. Relationships between fauna and people and the role of ethnozoology in animal conservation. Ethnobiol Conserv 1 (2): 1-57.

Badriansyah R, Kurnia I, Wiranata. 2015. Diversity of species of birds and ethno-ornithological studies in the forbidden forest custom built-in Putuy Village Petapahan Tapung Sub-District of Kampar District of Riau Province. Proceeding National Conference and Observer of Birds Indonesia. Bogor Agriculture Institute, Bogor, 13-14 February 2015. [Indonesia]

Balen, BV. 1999. Birds on fragmented islands: persistence in the forests of Java and Bali. Tropical Resource Management Papers, Wageningen University, The Netherlands.

Bezerra DM, de Araujo HF, Alves AGC. 2013. Birds and people in semiarid northeastern Brazil: Symbolic and medicinal relationships. Ethnobiol Ethnomed 9 (3): 1-11.

Bibby CJ, Burgess ND, Hill DA. 1992. Bird Census Techniques. Academic Press, London.

BirdLife International, 2003. Saving Asia's Threatened Birds: A Guide for Government and Civil Society. BirdLife International, Cambridge.

Blondel J. Ferry C, Frochot B. 1970. La methode des Indices Ponctuels d'Abondance (I.P.A) ou des releves d'avifaune par "Stations d'Ecoute". Alauda 38: 55-70.

Bonta M. 2011. Ethno-ornithology and Biological Conservation. In: Tidemann S, Gosler A (eds). Ethno-ornithology: birds, Indigenous People, Culture and Society. Earthscan, London.

Cunningham AB. 2001. Applied Ethnobotany: People, Wild Plant Use \& Conservation. Earthscan, London.

Dammerman KW. 1929. The Agricultural zoology of the Malay Archipelago: the Animals Injurious and beneficial to agriculture, horticulture and forestry in the Malay Peninsula, the Dutch East Indies and the Philippines. JH De Bussy Ltd, Amsterdam.

Dandeniya A, Algiriya P. Dewage D et al. 2015. Significance of birds in culture of Veddah: The indigenous people of Sri Lanka. J IRCHSS 1 (1): $1-16$.

Delacour J. 1947. Birds of Malaysia. MacMillan Co., London.

Der Ploeg JV, Weerd MV. 2010. Agta bird names: an ethno-ornithological survey in the Northern Sierra Madre Natural Park, Philippines. Forktail 26: 127-131.

Diamond J. Bishop KD. 1999. Etno-ornithology of the Ketengban People Indonesian New Guinea. In: Medin DL. Atran S (eds). Folk Biology. Massachusetts Institute of Technology, London.

Dickson JG, Conner RN, Fleet RR et al. 1979. The Role of Insectivorous in Forest Ecosystems. Academic Press, New York.

Dove MR. 1988. System of Cultivation in Indonesia: A case study of West Kalimantan. Gadjah Mada University Press, Yogyakarta. [Indonesia]

Ekwochi U, Osuorah CDI, Ndu IKK et al. 2016. Food taboos and Myths in South Eastern Nigeria: the beliefs and practice of mothers in the region. Ethnobiol Med 12: 7. 
Ellen RF. 1993a. Nualu ethnozoology a systematic inventory. CSAC Monograph 6 South-East Asia Series, Canterbury.

Ellen RF. 1993b. The cultural relations of classification: an analysis of Nualu animal categories from Central Ceram. Cambridge University Press, Cambridge.

Endri N, Iskandar J, Parikesit. 2015. Communal land forest management with zoning system and its effect on biodiversity of birds in Nagar Simanau, Solok Regency of West Sumatra. Proceeding National Conference and observer of birds Indonesia. Bogor Agriculture Institute, Bogor, 13-14 February 2015. [Indonesia].

Helvoort BV. 1981. Bird Populations in the Rural Ecosystems of West Java. Nature Conservation, Department of Agricultural, University of Wageningen, Wageningen, The Netherlands.

Hoogerwerf A. 1948. Distribution of birds in Java. Treubia 19: 116-127.

Hoogerwerf A. 1949a. De Avifauna van Tjibodas en Omgeving (Java). Koninklijke Plantentuin van Indonesie, Buitenzorg.

Hoogerwerf A. 1949b. De Avifauna van de Plantentuin te Buitenzorg. Koninklijke Plantentuin van Indonesie, Buitenzorg.

Howe HF, Westley LC. 1988. Ecological relationships of plants and animals. University Press, Oxford.

Hunn ES. 2010. Foreword. In: Tidemann S, Gosler A (eds). Ethnoornithology: Birds, Indigenous People, Culture and Society. Earthscan, London.

Iskandar J, Iskandar BS. 2015. Benefit of various birds in the song-bird contest and its impact to bird conservation in nature: A case study in Bandung, West Java. Pros Sem Nas Masy Biodiv Indon 1: 747-752. [Indonesia].

Iskandar J. 1980. Bird ecology research in several rural Citarum Watershed. [Hon. Thesis]. University of Padjadjaran, Sumedang. [Indonesian].

Iskandar J. 1998. Swidden cultivation as a form of cultural identity: the Baduy Case. [Ph.D Disertation]. University of Kent, Canterbury, England.

Iskandar J. 2007. Bird diversity and dynamics in society Sundanese. In: Bachtiar T, Setiawan H (eds). Natural salvage Sunda and other studies regarding the Sundanese culture. Sunda Research Center, University of Padjadjaran, Sumedang. [Indonesian]

Iskandar J. 2012. Ethnobiological and Sustainable Development. Research Center for Public Policy and Territorial, University of Padjadjaran, Sumedang. [Indonesian]

Iskandar J. 2014. Humans and the Environment with Various Amendment. Graha Ilmu, Yogyakarta. [Indonesian]

Iskandar J. 2015a. Biological diversity of animal type Benefit for Human Ecology. Graha Ilmu, Yogyakarta. [Indonesian]

Iskandar J. 2015b. Dilemma between hobby and business trade of birds and bird conservation. Proceeding National Conference and Observer of Birds Indonesia. Bogor Agriculture Institute, Bogor, 13-14 February 2015. [Indonesia]

Iskandar J. 2016. Ecology of birds in the countryside: A case study in the Citarum River Basin in West Java. Proceeding National Conference and Observer of Birds Indonesia. Atma Jaya University, Yogyakarta, 4-7 Februari 2016. [Indonesia]

Jepson P, Ladle RJ. 2005. Bird-keeping in Indonesia: conservation impacts and the potential for substitution-based conservation responses. Oryx 39: 442-448

Jepson P. 2011. Towards and Indonesian Bird Conservation Ethos: Reflections from a Study of Birds-keeping in the Cities of Java and Bali. In: Tidemann S, Gosler A (eds). Ethno-ornithology: Birds, Indigenous People, Culture and Society. Earthscan, London.

Jorgensen OH. 1976. Results of IPA-Censuses on Danish Farmland. Acta Ornithologica 14: 167-178
King B, Dickinson EC, Woodcock. 1975. A Field Guide to the Birds of South East Asia. Collins, London.

Kizungu B, Ntabaza M, Mburunge M. 1998. Ethno-ornithology of the Tembo in Eastern DRC (former Zeire): part one, Kolehe zone. African Study Monograph 19 (2): 103-113.

Kuroda N. 1933. Non-passerine: Birds of the Island of Java. Vol. 1, Kuroda, Tokyo.

LIPI. 2014. Present Biodiversity Indonesia. LIPI Press, Jakarta. [Indonesian]

Mackinnon J, Phillipps K, Balen BV. 1992. The birds in Sumatra, Java, Bali and Borneo. Center for Biology-LIPI. Bogor. [Indonesian]

Madoc GC. 1976. An Introduction to Malayan Birds. The Malayan Nature Society, Kuala Lumpur.

Milton GR, Marhadi A. 1989. An investigation into the Market-Netting of Birds in West Java, Indonesia. Directorate General of Forest Protection, Bogor.

Muiruri MN, Maundu P. 2011. Birds, People and Conservation in Kenya. In Tidemann S, Gosler A. (eds). Ethno-ornithology: Birds, Indigenous People, Culture and Society. Earthscan, London.

Newing H, Eagle CM, Puri RK et al. 2011. Conducting research in Conservation: Social Science Methods and Practice. Routledge, London.

Noerdjito M, Maryanto I. 2001. Types of Biological Protected Indonesian Legislation. Center for Biology-LIPI. Bogor. [Indonesian]

Pangau-Adam M, Noske R. 2011. Wildlife hunting and bird trade in Northern Papua (Irian Jaya), Indonesia. In: Tidemann S, Gosler A. (eds). Ethno-ornithology: Birds, Indigenous People, Culture and Society. Earthscan, London.

Partasasmita R, Iskandar J, Malone N, 2016. Karangwangi people's (South Cianjur, West Java, Indonesia) local knowledge of species, forest utilization and conservation. Biodiversitas 17 (1): 154-161.

Partasasmita R, Muhammad GI, Iskandar J. 2015. Population, occupational and public knowledge about barn owl birds (Tyto alba javanica JF Gmelin 1788) at Universitas Padjadjaran Campus of Jatinangor, Sumedang District. Pros Sem Nas Masy Biodiv Indon 1: 1570-1576. [Indonesia].

Roldan-Clara BX, Lopez-Medellin I, Espejel E at el. 2014. Literature Review of the use of bird as pets in Latin-America, with a detailed perspective on Mexico. Ethnobiol Conserv. DOI: 10.15451/ec201410-3.5-1-18

Sillitoe P. 2003. Managing Animals in New Guinea. Routledge, London.

Smythies BE. 1960. The Birds of Borneo. The Sabah Society \& The Malayan Nature Society, Kuala Lumpur.

Sodhi NS, Sekercioglu CG, Barlow J et al. 2011.Conservation of Tropical Birds. Wiley-Blackwell, West Sussex, UK.

Sodhi NS, Sekercioglu CH, Balow J et al. 2011. Conservation of Tropical Birds. Wiley-Blackwell, West Susex, UK.

Strachclyda T. 2015. Study of Ethno-ornithology birds as well as its role in the village community Karangwangi Cianjur Regency, West Java. [Research Report]. University of Padjadjaran, Sumedang. [Indonesian]

Teixeira PHR, Thel TN, Ferreira JMR et al. 2014. Local knowledge and exploitation of the avian fauna by a rural community in the semi-arid zone of Northeastern Brazil. Ethnobiol Med 10 (81): 1-10.

Tidemann S, Chirgwin S, Sinclair JS. 2010. Indigenous knowledge, Birds that that Have 'Spoken' and Science. In: Tidemann S, Gosler A (eds). Ethno-ornithology: Birds, Indigenous People, Culture and Society. Earthscan, London.

Toledo, V.M. 2002. Ethnoecology: A Conceptual Framework for the Study of Indigenous Knowledge of Nature. In Stepp JR, Wyndham FS, Zarger RK. (eds). Ethnobiology and Biocultural. The International Society of Ethnobiology, Georgia. 